\title{
TRADISI ZIARAH KUBRO MASYARAKAT KOTA PALEMBANG DALAM PERSPEKTIF HIERARKI NILAI MAX SCHELER
}

\section{Prima Amri}

Fakultas Filsafat Universitas Gadjah Mada

Email: prima.amri@mail.ugm.ac.id

\section{Septiana Dwiputri Maharani}

Fakultas Filsafat Universitas Gadjah Mada

Email: septiana.dm@ugm.ac.id

\section{Abstrak}

Latar belakang artikel ini adalah kearifan lokal masyarakat Kota Palembang khususnya pada tradisi Ziarah Kubro yang sesungguhnya memiliki nilai-nilai filosofis namun pada kenyataannya masih dipahami sebatas ritual belaka. Artikel ini bertujuan untuk menganalisis tradisi Ziarah Kubro melalui perspektif hierarki nilai Max Scheler. Artikel ini menganalisis secara mendalam nilai-nilai yang terkandung di dalam tradisi Ziarah Kubro dengan menggunakan metode deskriptif analitis sebagai bentuk kajian kepustakaan. Berdasarkan hasil penelitian dapat diperoleh kesimpulan bahwa tradisi Ziarah Kubro mengandung nilai-nilai filosofis, yaitu nilai kenikmatan, kehidupan, kejiwaan, dan religius. Berdasar perspektif hierarkhi nilai Max Scheler maka nilai religius merupakan nilai tertinggi yang dijunjung tinggi oleh masyarakat Kota Palembang. Nilai-nilai tersebut dapat dirasakan melalui preferensi yang dipengaruhi oleh perasaan cinta dan benci. Hal ini berimplikasi pada sikap masyarakat Kota Palembang yang senantiasa melaksanakan dan melestarikan tradisi ini hingga pada generasi selanjutnya dengan harapan mendapat keberkahan serta semakin religiusnya kehidupan di dalam masyarakat.

Kata Kunci: Ziarah Kubro Palembang, hirarki nilai Max Scheler, religius

\section{Abstract}

The background of this article is the local wisdom of people of Palembang city, in the form of a tradition called Ziarah Kubro (The Great Pilgrimage) which actually contains philosophical values but in practice it is still understood as 
merely a ritual. This article aims to analyze the Ziarah Kubro tradition employing perspective of Max Scheler's hierarchy of values. This article provides indepth analysis regarding the values contained in the tradition of Ziarah Kubro using descriptive analytics as a form of literature review. Results of the study suggest that Ziarah Kubro tradition contains philosophical values, namely the value of pleasure, vitality, spirituality, and religius. Based on Max Scheler hierarchical perspective, religius values are the highest values upheld by the people of Palembang City. These values can be sensed through preferences influenced by the feelings of love and hate. This preference has implications towards the attitudes of the Palembang people who always carry out and preserve this tradition to the next generation in the hope of attaining blessings and increasing religious life in society.

Keywords: Ziarah Kubro Palembang, Max Scheler's Hierarcy of Value, Religious

\section{PENDAHULUAN}

Kebudayaan sebagai hasil dari cipta, rasa, dan karsa manusia dapat berupa suatu kompleks gagasan, ide, dan pikiran manusia (Sulaiman, 1995: 12). Adapun wujud kebudayaan dapat bersifat nyata yaitu berupa aktivitas manusia yang melakukan interaksi ataupun dalam suatu sistem sosial tertentu (Kaelan, 2014: 97). Mengulas tema kebudayaan khususnya yang berlaku dalam kelompok masyarakat tertentu maka akan sangat erat kaitannya dengan local wisdom (kearifan lokal) yang sering didefinisikan sebagai sebuah sistem dalam tatanan kehidupan sosial, politik, budaya, ekonomi, serta lingkungan yang hidup di tengah-tengah masyarakat lokal sebagai ciri khas sebuah daerah (Thamrin, 2013: 46).

Kearifan lokal sebagai ciri khas daerah yang berdimensi positif pastilah mendapat dukungan atau penerimaan dari masyarakat setempat. Salah satu masyarakat yang memiliki kearifan lokal yang khas adalah masyarakat Kota Palembang, Sumatera Selatan. Masyarakat Palembang senantiasa menjaga tradisi dan nilainilai luhur yang telah dipegang teguh dari generasi ke generasi. Palembang yang terkenal dengan keindahan Sungai Musi memiliki kearifan lokal yang dipengaruhi oleh berbagai faktor, terutama faktor historis. Sebagai kota tertua di Indonesia dan pernah menjadi pusat Kerajaan Sriwijaya, Palembang telah menjadi pusat perdagangan para 
pedagang Arab, Melayu, India, dan bahkan Tiongkok. Kondisi ini membuat masyarakat kota Palembang memiliki budaya yang beragam sebagai konsekuensi dari proses interaksi yang terjadi.

Fakta di atas menjadikan Palembang dikenal secara luas sebagai masyarakat yang fokus pada perdagangan maupun kewirausahaan dengan dilandasi nilai-nilai keislaman. Fakta tersebut di atas didukung oleh data yang menunjukkan kuatnya penyebaran Islam di Palembang melalui berbagai cara. Penyebaran Islam yang dominan terjadi melalui jalur perdagangan oleh para pedagang dari Timur Tengah. Puncaknya adalah dengan didirikannya Kesultanan Palembang Darussalam pada abad ke-17, sehingga Palembang dikenal sebagai pusat perdagangan dengan dunia Arab dan pusat pembelajaran Islam (Collins, 2004: 95). Kehidupan masyarakat Palembang yang sangat kental dengan nilai-nilai religius membuat masyarakatnya memiliki nuansa religius dalam hal kearifan lokal. Wujud kearifan lokal tersebut adalah pada sistem religi yang khas, yaitu pada tradisi Ziarah Kubro.

Tradisi Ziarah Kubro dilakukan oleh masyarakat di Kampung Arab Palembang. Tradisi ini dilakukan menjelang bulan Ramadan atau lebih tepatnya pada 10 hari terakhir bulan Syakban / 10 hari menjelang bulan Ramadan. Sampai dengan sekarang, tradisi Ziarah Kubro tersebut tetap bertahan. Meskipun diyakini bahwa modernisasi telah mempengaruhi sendi-sendi kehidupan masyarakat, namun ternyata tradisi Ziarah Kubro tersebut tetap mampu bertahan sebagai sebuah bentuk kearifan lokal. Masuknya berbagai pengaruh asing justru kemudian menjadi tantangan untuk dapat membina dan membentuk kebudayaan baru yang asli Indonesia (Koentjaraningrat, 2015: 38). Jika dahulu Ziarah Kubro hanya dianggap sebagai sebatas ritual keagamaan, namun saat ini Ziarah Kubro mampu memberikan daya tarik ekonomi bagi daerah sekitarnya sehingga tepat kiranya jika hal ini kemudian memberikan dampak positif bagi perekonomian Kota Palembang.

Berkembangnya orientasi nilai yang muncul pada tradisi Ziarah Kubro masyarakat Kota Palembang tersebut di atas akan dikaji oleh peneliti melalui perspektif filsafat nilai. Melalui pendekatan filsafat nilai maka seluruh persoalan nilai akan dianalisis secara 
mendalam. Mengapa filsafat nilai? Karena pada kenyataannya kehidupan manusia akan selalu terikat dan tidak dapat dilepaskan dari nilai. Nilai melandasi pembentukan dan pengembangan diri manusia, karena nilai merupakan sebuah daya yang mendorong tindakan manusia dan memberinya makna. Nilai membantu manusia mengarahkan hidupnya. Karenanya, manusia dalam hidup harus memerhatikan ide atau cita etika yang didasari oleh kebajikan yang tinggi. Sebagai makhluk sosial yang tidak dapat hidup sendiri tanpa bantuan manusia lainnya, manusia selalu memadukan kontak dengan manusia lain agar tidak terjadi kekacauan dalam kehidupan bermasyarakat (Alfan, 2013: 31).

Sebagaimana disebutkan di atas bahwa penelitian ini bertujuan untuk mencari nilai-nilai yang terkandung dalam tradisi Ziarah Kubro dan berusaha memberikan gambaran mengenai nilai yang lebih diutamakan dalam tradisi tersebut. Perspektif Max Scheler sebagai seorang filosof yang mengkaji aksiologi akan digunakan lebih lanjut untuk menemukan hierarkhi nilai pada tradisi Ziarah Kubro. Hal ini sekaligus menunjukkan posisi penelitian ini bila dibandingkan penelitian lain yang mengambil tema serupa tentang aksiologi. Melalui penelitian ini diharapkan agar potensi kearifan lokal, khususnya kearifan lokal Kota Palembang dalam tradisi Ziarah Kubro dapat lebih diketahui oleh masyarakat dan mendapat landasan filosofis yang kuat terkait nilai yang dibangun.

\section{PEMBAHASAN}

\section{Tradisi Ziarah Kubro Masyarakat Kota Palembang}

Masyarakat Kota Palembang terdiri dari beberapa etnis dan agama yang menjadi satu kesatuan di dalam masyarakat yang rukun dan damai. Palembang dikenal sebagai daerah yang jarang sekali terjadi konflik horizontal yang merusak tatanan hidup masyarakat. Di dalam kehidupan masyarakat yang beragam tersebut, terdapat salah satu sistem religi yang menjadi kearifan lokal di Palembang yaitu tradisi Ziarah Kubro. Tradisi yang dilakukan oleh masyarakat di Kampung Arab Palembang ini terus dijaga secara turun temurun hingga saat ini. 
Secara harfiah, Ziarah Kubro berarti ziarah kubur. Ziarah dalam pengertian umum di Indonesia berupa kunjungan ke makam, masjid dan relik-relik tokoh agama raja dan keluarganya dan terutama ke makam para wali penyebar Agama Islam. Kharisma leluhur dalam hal ini seorang ulama juga dapat diwujudkan dalam bentuk dan hiasan kubur yang beraneka ragam, sesuai tradisi dan bangunan seni yang dikuasai atau disukai. Kharisma para wali penyebar agama Islam begitu melekat hingga sekarang, sehingga banyak dikunjungi masyarakat (Purwadi, 2010: 17-18). Masyarakat Kota Palembang menyadari dan memahami besarnya peran para ulama dalam menyebarkan Agama Islam dan untuk itu mereka melaksanakan tradisi Ziarah Kubro untuk menghormati serta mendoakan para ulama tersebut. Ziarah Kubro merupakan tradisi masyarakat Palembang dengan mengunjungi makam para ulama dan pendiri Kesultanan Palembang Darussalam seminggu menjelang Ramadhan.

Ziarah Kubro mulai dikenal luas ketika Islam berkembang pesat di Palembang pada sekitar abad ke-16 yang ditandai dengan meningkatnya peran warga keturunan Arab menjadi penasihat ataupun guru spiritual raja. Puncaknya terjadi pada awal abad ke-19, Palembang menjadi pusat komunitas Arab di Pulau Sumatra, seperti layaknya Aceh. Kondisi ini dapat terjadi karena kebijakan Sultan Mahmud Badr-al-Din sebagai Sultan Palembang Darussalam yang memberikan ruang bagi komunitas warga keturunan Arab untuk menetap di wilayah Palembang dan menjalin hubungan yang harmonis dengan masyarakat lokal (Berg, 1989: 72-77). Sejak saat itu tradisi Ziarah Kubro mulai menjadi ritual bersama warga keturunan Arab dan warga Palembang. Hal ini terjadi ketika Palembang berada pada masa Kesultanan Palembang Darussalam (1659-1823). Artinya telah terjadi akulturasi budaya Arab dan Palembang seperti dengan adanya pawai diiringi prajurit berpakaian khas Melayu Palembang dan mengunjungi makam pendiri ataupun penguasa Palembang terdahulu. Tradisi ini bukan hanya tradisi keagamaan melainkan juga merupakan tradisi untuk menghormati jasa para ulama ataupun pendiri kesultanan Palembang Darussalam. 
Tradisi Ziarah Kubro ini dimaknai sebagai upaya untuk introspeksi diri dan mengingatkan para peserta ziarah akan besarnya peran ulama dan para pemimpin Kesultanan Palembang Darussalam dalam menyebarkan Agama Islam hingga pada masanya Palembang dapat menyaingi atau bahkan menyalip Aceh sebagai pusat pembelajaran Agama Islam. Palembang pada masa itu mengalami perekonomian yang sangat maju dengan berbekal ekspor lada dan timah sebagai komoditas utama dalam mendorong laju perekonomian (Kersten, 2017: 47).

Tradisi Ziarah Kubro diyakini hanya ada di Palembang dan tidak ada di daerah lain. Puncak Ziarah Kubro tersebut dilakukan di kompleks pemakaman Kesultanan Palembang Darussalam, khususnya di kampung Arab. Meskipun realitasnya warga keturunan Arab yang menetap dan membentuk suatu komunitas tidak hanya di Kota Palembang, karena faktanya pada daerah lain termasuk Kota Palembang juga terdapat perkampungan warga keturunan Arab. Hal ini tidak lepas pula dari kebijakan Belanda untuk mengantisipasi meningkatnya populasi warga keturunan Arab dengan membangun perkampungan khusus bagi mereka (Qurtuby, 2017: 51).

Rangkaian acara pada tradisi Ziarah Kubro sudah dimulai sejak Jumat pagi setelah salat Subuh. Diawali dengan pembacaan Burdah dan Haul di rumah panggung yang telah berusia ratusan tahun, dikenal dengan sebutan Rumah Bari. Lalu ribuan peziarah itu akan berangkat bersama-sama melakukan ziarah kubur ke pemakaman para ulama dan auliya yang terdapat di kota Palembang. Ziarah ke makam para ulama dan auliya ini berlangsung secara bertahap selama tiga hari berturut-turut. Di hari pertama, para peziarah mengunjungi Gubah Al-Habib Ahmad bin Syech Shahab, tempat sebagian besar kaum alawiyyin dimakamkan dan pemakaman Habib Aqil bin Yahya. Di akhir kegiatan tersebut, para peziarah diharapkan akan mendapatkan ilmu dan teladan dari para ulama dan auliya yang telah mendahului, dan menambah ilmu pengetahuan dan kebudayaan Islam di Indonesia dan mancanegara.

Jemaah dan ulama tersebut kemudian disambut keturunan kesultanan, yakni Sultan Iskandar Mahmud Badaruddin. Mereka berdoa bersama untuk para ulama, pendiri, dan pemimpin kesultanan 
terdahulu. Setelah itu, rangkaian kegiatan ditutup dengan makan bersama. Menu yang disajikan antara lain, nasi minyak dengan daging kambing bakar. Kegiatan ini juga sudah menjadi agenda wisata religi dan wisata budaya di Kota Palembang. Tidak hanya menarik peziarah dari Kota Palembang saja, para peziarah dari Pulau Jawa, Kalimantan, dan daerah lain di Indonesia juga ikut memeriahkan. Bahkan para tokoh ulama dan tamu dari mancanegara juga ikut meramaikan, seperti dari Malaysia, Singapura, Thailand, Brunai Darussalam, Kuwait, Yaman, serta Arab Saudi.

\section{Perspektif Max Scheler Tentang Nilai}

Max Scheler dilahirkan di Munchen Jerman Selatan pada tahun 1814, di suatu daerah yang rnasyarakatnya mayoritas Katholik. Ibunya seorang wanita Yahudi, sedang ayahnya beragama Protestan. Pada waktu berumur 15 tahun (1889), Scheler belajar di Gymnasium (sekolah menengah) di Munchen. Di Munchen Scheler masuk agama Katholik. Scheler kemudian diangkat menjadi Profesor pada Universitas Koln. Scheler merangkap sebagai Direktur Institut Penelitian di bidang Ilmu Sosial pada Universitas tersebut. Filsafat Scheler sangat kental dengan pengaruh fenomenologi Edmund Husserl yang memahami fenomenologi sebagai suatu analisis deskriptif dan introspektif mengenai kedalaman dari semua bentuk kesadaran dan pengalaman langsung dibidang religius, moral, estetis, konseptual, serta indrawi. Max Scheler meninggal pada tahun 1928 karena serangan jantung ketika diundang menjadi Profesor di Frankfurt, sebelum sempat memulai kuliahnya (Parmono, 1993: 43$44)$.

Scheler menyatakan bahwa nilai tidak tergantung pada tujuan, nilai juga tidak berlaku tanpa tujuan; agaknya nilai melekat dalam sasaran dari kecenderungan sebagai dasar. Hal tersebut menyebabkan nilai sebagai dasar dari sasaran, dan karena hanya tujuan yang memiliki isi yang melambangkan sebuah etika material nilai, maka nilai harus bersifat a priori yang berkaitan dengan semua isi pengalaman yang dilambangkannya (Frondizi, 2009: 112). Secara fenomenologis, teori nilai Scheler mengarah kepada kesadaran emosional yang pada awalnya melalui konteks hierarki nilai-nilai 
(Gangas, 2011: 356). Nilai adalah suatu kualitas yang dalam keberadaannya tidak bergantung pada pengembannya. Nilai bagi Scheler merupakan hal yang otonom, yang tidak dapat diganggu atau dipengaruhi oleh perubahan yang terjadi pada objek yang digabungnya, nilai adalah kualitas yang independen. Namun demikian, nilai dalam menunjukkan eksistensinya memerlukan pengemban sebagai perantara nilai hingga dapat diketahui manusia.

Objektivisme Scheler sangat erat hubungannya dengan pandangannya tentang nilai yang mutlak. Scheler menolak semua teori yang relativistis. Scheler menolak pendapat bahwa nilai memiliki eksistensi dalam hubungannya dengan manusia, baik susunan fisik maupun psiko-fisiknya. Scheler juga menolak ketergantungan nilai pada hidup. Apabila nilai tergantung pada hidup, maka akan meniadakan kemungkinan untuk dapat menyifatkan nilai pada hidup itu sendiri. Apabila nilai tergantung pada hidup, maka akibatnya kebaikan di dalam hidup akan merupakan fakta yang tidak memerlukan nilai. Scheler juga menolak relativitas dari pertimbangan sejarah nilai. Relativitas historis berusaha menurunkan nilai dari benda historis dengan memandangnya sebagai hasil sejarah, sehingga merupakan hasil dari rangkaian perubahan. Relativisme historis melakukan kesalahan, karena tidak memperhatikan hakikat nilai yang independen dan mengacaukan perubahan riil yang terjadi pada benda dan norma dengan variasi nilai (Jirzanah, 2008: 93).

Manusia perlu membedakan antara nilai-nilai (Werte, values) dengan apa yang bernilai, realitas bernilai (Guter, goods). Sebagaimana warna merah selalu muncul pada sebuah realitas berwarna merah, misalnya dinding merah, baju merah; begitu pula nilai juga selalu muncul pada suatu benda, perbuatan, atau keadaan, misalnya makanan sehat, pola hidup sehat, pemikiran benar, tindakan benar, keadaan aman, peralatan aman dsb. Hal-hal yang dilekati nilai tersebut bersifat a posteriori, yaitu bisa ada, dan juga bisa tidak ada; namun nilai itu sendiri adanya bersifat a priori, keberadaannya mendahului pengalaman. Sebelum terwujud dan melekat pada hal yang bernilai, nilai sudah berada pada dunia nilai. Nilai merupakan kompleks kualitas yang memiliki keselarasan dengan kecenderungan 
kodrat manusia, sehingga manusia cenderung tertarik untuk mengarah pada kualitas tersebut, dan kualitas tersebut dirasa layak terwujud dalam hidupnya. Dengan demikian nilai merupakan kualitas yang dapat ditangkap perasaan manusia sebagai yang memiliki daya tarik, baik sebelum terwujud maupun setelah terwujud pada yang bernilai. Nilai tidak ditemukan dengan pikiran (secara rasional), melainkan dengan suatu "perasaan intensional".

Max Scheler berpendapat bahwa meskipun seluruh nilai memiliki objektivitas dan hubungan antar inti-intinya tidak bergantung baik pada realitas maupun secara aktual pada hubungannya dengan hal bernilai yang mewujudkannya, namun terdapat suatu perbedaan yang berupa skala relativitas. Kenyataan bahwa nilai itu relatif, bukan berarti membuat nilai menjadi subjektif. Nilai dari sesuatu yang menyenangkan adalah relatif bagi manusia yang dianugerahi perasaan indrawi, sedangkan nilai yang dimaksud oleh emosi murni, yaitu tindakan preferensi dan cinta, adalah absolut, sebab emosi murni tidak bergantung pada perasaan indrawi dan inti kehidupan. Semakin kurang relatif suatu nilai, maka nilai tersebut semakin tinggi, nilai tertinggi dari semua nilai adalah nilai absolut (Owens, 1966: 148). Artinya, nilai memiliki hakikat sebagai tindakan preferensi yang bersifat absolut, dan disertai oleh emosi murni seperti cinta.

\section{Hierarki Nilai Max Scheler}

Max Scheler membagi nilai ke dalam empat struktur nilai yang tersusun menjadi susunan hierarki nilai dari tingkat yang lebih tinggi menurun ke tingkat yang lebih rendah, yang bersifat a priori. Hierarki ini tidak dapat dideduksikan secara empiris, tetapi terungkap melalui tindakan preferensi, yaitu melalui intuisi preferensi-evidensi. Hierarki nilai bersifat mutlak dan mengatasi segala perubahan historis serta membangun suatu sistem acuan yang absolut dalam etika, yang merupakan dasar untuk mengukur dan menilai berbagai macam etos, dan segala perubahan moral dalam sejarah (Kabelen, 2014: 64). Melalui keseluruhan realitas nilai, hanya terdapat satu susunan hierarki yang menyusun seluruh nilai. Artinya, pada hierarkhi nilai tersebut sebuah nilai tertentu dapat memiliki 
kedudukan lebih tinggi atau lebih rendah dibandingkan dengan nilai yang lainnya. Susunan tersebut terdapat dalam inti setiap nilai, dan hal ini tidak hanya terdapat pada nilai yang diketahui saja, seperti pada perbedaan nilai baik dan buruk. Setiap nilai, baik yang diketahui maupun tidak, memiliki tempat tersendiri dalam hierarki nilai (Wahana, 2016: 192).

Berdasarkan pendekatan di atas dapat dipahami bahwa suatu nilai akan menempati posisi yang lebih tinggi daripada nilai yang lain dalam sebuah tindakan yang melibatkan pemahaman khusus terhadap nilai. Hal inilah yang disebut dengan tindakan preferensi, yaitu tindakan yang melibatkan sebuah pemahaman akan tinggi dan rendahnya suatu nilai. Seseorang tidak diperkenankan memperkirakan bahwa tingkatan suatu nilai dapat dirasakan dengan rasa yang sama terhadap nilai itu sendiri. Dengan demikian nilai yang lebih tinggi tersebut dipahami dengan tindakan mendahulukan, mengunggulkan, atau mengutamakan dengan tindakan meremehkan terhadap nilai yang lebih rendah. Aspek utama yang akan mempengaruhi hierarki nilai seseorang adalah pengetahuan dan pengembangan diri. Pada konteks ini pengembangan diri dan keseimbangan internal adalah dasar untuk hubungan yang harmonis dengan sifat non-manusia (McCune, 2014: 67).

Tingkatan suatu nilai merupakan hal yang keberadaannya memang sudah demikian berdasarkan hakikatnya, dan dapat dirasakan melalui preferensi. Perasaan cinta dan benci adalah tindakan yang mempengaruhi preferensi. Manusia cenderung tertarik dengan yang lebih besar atau nilai positif, serta cenderung menjauh atau menolak nilai negatif. Hal tersebut hadir dalam setiap pengalaman pada setiap perangkat nilai-nilai. Tindakan preferensi berbeda dengan sekedar tindakan memilih. Tindakan preferensi adalah tindakan yang mengutamakan pemilihan atau keinginan tanpa menunjukkan adanya kecenderungan, sedangkan tindakan memilih adalah tindakan kecenderungan yang telah mencakup pengetahuan tentang nilai (Scheler, 1973: 104).

Terdapat lima macam kriteria dalam menentukan hierarki suatu nilai sebagai berikut (Jirzanah, 2008: 94; Dekken, 1974: 53-55): 
1. Sifat yang tahan lama. Nilai dikatakan tahan lama pada posisi nilai itu sendiri bukan pada pengembannya. Nilai yang semakin tahan lama terhadap segala kondisi merupakan nilai yang memiliki kedudukan yang tinggi diantara nilai yang tidak tahan lama. Nilai yang memiliki tingkat tahan lama yang rendah biasanya merupakan kualitas yang dapat diketahui melalui indrawi manusia.

2. Sifat dapat dibagi. Nilai yang tidak dapat dibagi-bagi karena keluasannya merupakan nilai yang paling tinggi. Berbanding terbalik dengan nilai yang masih dapat dibagi-bagi merupakan nilai yang memiliki tingkatan rendah dibanding yang tidak dapat dibagi. Artinya nilai dapat ditentukan oleh berbagai hal seperti kualitas, ukuran, serta keluasan pengemban nilai tersebut.

3. Tidak tergantung pada nilai lain. Scheler berpendapat karena semua nilai didasarkan pada nilai yang lebih tinggi, maka ada nilai yang paling tinggi, yaitu nilai religius. Scheler dalam hal ini kembali pada monisme aksiologis seperti yang pernah berlaku pada jaman pertengahan. Artinya nilai religius merupakan nilai yang tidak bergantung pada nilai lain yang ada di bawahnya. Nilai tertinggi merupakan nilai yang tingkat otonominya sangat tinggi.

4. Sifat membahagiakan. Tingginya hierarkhi nilai tidak ditetapkan melalui kedalaman kenikmatan, tetapi melalui kedalaman kebahagiaannya. Kebahagiaan berbeda dengan kenikmatan, meskipun ada kemungkinan kenikmatan merupakan hasil dari kebahagiaan. Kebahagiaan juga tidak selalu didahului oleh suatu keinginan. Kebahagiaan terjadi melalui persepsi sentimental yang tenang dan dikandung oleh benda yang bernilai secara positif. Satu nilai lebih membahagiakan daripada nilai yang lain apabila eksistensinya tidak tergantung pada persepsi sentimental terhadap nilai yang lain tersebut. Kebahagiaan dapat tercapai tanpa ada kebahagiaan lain yang mendahuluinya.

5. Sifat tidak tergantung pada kenyataan tertentu. Nilai mengacu pada esensi nilai itu sendiri, artinya tidak tergantung atas relativitas dari sifat pengemban nilai. Di antara berbagai benda ada perbedaan skala relativitas. Sesuatu yang menyenangkan akan relatif bagi seseorang, karena tergantung perasaan sensitifnya, sebaliknya nilai adalah mutlak. 
Dalam hierarki nilainya Max Scheler membagi tingkatan nilai menjadi 4 yaitu (Jirzanah, 2008: 95; Scheler, 1916: 122-126):

1. Nilai Kenikmatan (Kesenangan)

Tingkat pertama ini berisi deretan nilai-nilai yang mengenakkan dan tidak mengenakkan, yang menyebabkan seseorang menjadi senang atau menderita tidak enak. Pada tingkatan terendah dapat ditemukan deretan nilai kesenangan dan nilai kesusahan atau kenikmatan dan kepedihan. Tingkatan nilai berkaitan dengan fungsi perasaan indriawi, yaitu rasa nikmat dan rasa sakit atau pedih. Rumusan bahwa kesenangan lebih disukai daripada ketidaksenangan tidak ditetapkan berdasarkan pengamatan, melainkan a priori (pengalaman yang mendahului dan tidak berdasarkan pengamatan empiris), dan termuat dalam inti nilai.

\section{Nilai Vital (Kehidupan)}

Tingkat kedua ini berisi deretan nilai-nilai yang penting bagi kehidupan, misalnya kesehatan, kesegaran badan, dan kesejahteraan umum. Nilai ini terdiri atas nilai-nilai kehidupan, yang meliputi rasa halus, luhur, atau lembut hingga yang kasar atau biasa, juga bagus yang berlawanan dengan yang jelek. Nilai yang diturunkan dari sini adalah kesejahteraan, baik pribadi maupun komunitas. Nilai menghadirkan perasaan yang tidak bergantung pada apapun dan tidak dapat direduksikan pada tingkat yang lebih tinggi (nilai spiritual) atau tingkat yang lebih rendah (nilai kesenangan).

3. Nilai Kejiwaan

Nilai ini memiliki sifat tidak bergantung pada seluruh lingkungan badaniah dan lingkungan alam sekitar. Tingkat nilai ini lebih tinggi dari kedua tingkat nilai sebelumnya. Artinya, orang harus berani dan wajib untuk mengorbankan nilai vitalitas demi nilai kejiwaan. Tingkat ketiga ini berisi nilai-nilai kejiwaan yang sama sekali tidak tergantung pada keadaan jasmani maupun lingkungan. Nilai-nilai ini dibedakan secara hierarkhis sebagai berikut: a). Nilai keindahan dan berbagai nilai estetis murni yang lain. b). Nilai kebenaran, yang seharusnya dibedakan dengan benar dan salah (melanggar). c). Nilai pengetahuan murni yang direalisasikan oleh filsafat. Nilai pengetahuan murni ini dilawankan dengan pengetahuan yang dihasilkan oleh ilmu positif. 


\section{Nilai Kerohanian atau Religius}

Tingkat keempat ini berisi modalitas nilai yang suci dan tidak suci. Nilai kerohanian ini tidak dapat direduksi menjadi nilai kejiwaan dan memiliki keberadaan yang khas dengan menyatakan diri (dalam berbagai objek) sebagai yang mutlak. Tingkat nilai ini tidak bergantung pada perbedaan waktu dan perbedaan orang yang membawanya. Tanggapan terhadap nilai biasanya diwujudkan dalam beriman dan tidak beriman, kagum, memuji, dan menyembah. Tindakan yang terjadi dalam mencapai nilai ini adalah jenis cinta khusus yang secara hakiki terarah pada pribadi. Dengan demikian, tingkatan nilai ini terdiri atas nilai-nilai pribadi. Nilai turunannya adalah nilai dalam pemujaan, sakramen, dan bentuk-bentuk ibadah, sejauh terkait dengan pribadi yang dipuja.

\section{Tradisi Ziarah Kubro dalam Analisis Hierarki Nilai Max Scheler}

Bukan tanpa alasan ketika tradisi Ziarah Kubro pada masyarakat Palembang dilaksanakan menjelang bulan suci Ramadan. Tradisi ini bagi masyarakat Kota Palembang merupakan sarana untuk mengingat kembali jasa para ulama serta media untuk mendoakan para ulama tersebut. Selain itu, tradisi Ziarah Kubro juga merupakan wujud syukur kepada Sang Pencipta yang kemudian dilakukan melalui berbagai doa yang dilantunkan.

Melalui tradisi Ziarah Kubro, kebersamaan umat Islam terus terpelihara dan terjalin dengan erat. Masyarakat yang melaksanakan tradisi ini berbondong-bondong berjalan kaki dari jarak yang jauh dengan harapan agar Kota Palembang khususnya dan kehidupan mereka lebih diberkahi lagi serta dijauhkan dari segala musibah yang akan menimpa kehidupannya. Selain beberapa hal yang sudah disebutkan di atas, tradisi Ziarah Kubro juga sekaligus menjadi ajang introspeksi diri terhadap segala perbuatan yang telah dilakukan dalam satu tahun yang telah lalu.

Sebagai salah satu wujud kearifan lokal masyarakat Palembang, tradisi Ziarah Kubro memiliki makna, tujuan serta nilai tertentu. Nilai yang terdapat dalam tradisi Ziarah Kubro tersebut bersifat independen dan tidak didasarkan pada penilaian subyek melainkan begitu apa adanya. Berdasarkan perspektif hierarkhi nilai 
Max Scheler maka nilai-nilai yang terkandung dalam tradisi Ziarah Kubro dapat dijabarkan sebagai berikut :

\section{A. Nilai Kenikmatan}

Pada tradisi Ziarah Kubro masyarakat Kota Palembang terkandung nilai kenikmatan. Nilai ini dapat ditemukan pada rangkaian tradisi Ziarah Kubro yang selalu dilakukan dengan makan bersama. Meskipun sesungguhnya tujuan dari tradisi ini tidak sekedar untuk menikmati makanan yang tersedia di akhir rangkaian acara, melainkan memiliki tujuan yang lebih tinggi lagi yaitu sebagai sarana untuk refleksi diri. Selain kenikmatan dari menikmati hidangan, nilai kenikmatan akan indahnya kebersamaan juga dapat dinikmati pada tradisi Ziarah Kubro. Meskipun demikian, sesungguhnya porsi nilai kenikmatan yang dapat ditemukan pada tradisi Ziarah Kubro sangat sedikit.

B. Nilai Vital atau kehidupan

Nilai vital adalah nilai yang berkaitan dengan suatu tujuan yang penting bagi kehidupan. Nilai ini terdiri atas nilai-nilai rasa kehidupan, yang dapat berupa nilai kesejahteraan, baik pribadi maupun komunitas (Alfan, 2013: 93). Tradisi Ziarah Kubro erat kaitannya dengan nilai vital atau kehidupan. Nilai vital dalam tradisi ini identik dengan adanya harapan bahwa setelah melaksanakan tradisi ini akan menjadi lebih sehat dan bugar. Seluruh proses ziarah yang harus dilakukan dengan cara berjalan kaki akan berdampak positif pada kesehatan para peserta yang melakukan tradisi ini.

Meskipun nilai vital ini bukan yang utama, namun hal ini merupakan salah satu pendorong bagi peserta untuk melaksanakan tradisi Ziarah Kubro. Prosesi Ziarah Kubro yang dilaksanakan secara bersama-sama dengan berjalan kaki akan meningkatkan metabolisme tubuh sehingga tubuh menjadi sehat dan dapat melaksanakan aktivitas sehari-hari dengan lancar. Dengan kondisi tubuh yang sehat maka produktivitas kerja akan menjadi lebih baik sehingga dapat bekerja dengan penuh semangat untuk memenuhi kebutuhan hidup mereka.

Adapun nilai vital dalam tradisi Ziarah Kubro yang berkaitan dengan kesejahteraan kehidupan bersama adalah terciptanya hubungan yang harmonis antar sesama manusia. Keharmonisan 
hubungan sosial yang selalu stabil akan berdampak pada tiadanya konflik yang merupakan penyebab rusaknya tatanan hidup masyarakat sehingga berbagai konflik horizontal di dalam kehidupan dapat semakin diminimalisir.

C. Nilai Kejiwaan

Pada nilai kejiwaan hal-hal yang berkaitan dengan dimensi fisik seperti yang muncul pada nilai kenikmatan dan nilai vital sudah tidak diutamakan lagi. Pemenuhan hal-hal yang berpengaruh secara fisik bagi manusia haruslah dikorbankan demi nilai kejiwaan ini. Nilai kejiwaan dalam Ziarah Kubro adalah berupa dorongan untuk mendapatkan ketentraman jiwa sehingga tercapai ketenangan batin dari segala permasalahan hidup. Nilai ini tidak berpengaruh secara langsung pada fisik atau kehidupan manusia, namun lebih kepada aspek batiniah yang ditingkatkan. Dengan melakukan Ziarah Kubro manusia menjadi lebih mengingat dari mana ia berasal dan kemana mereka akan kembali.

Ziarah Kubro telah menjadi oase bagi problematika kehidupan perkotaan masyarakat Palembang yang begitu rumit. Dengan melakukan Ziarah Kubro masyarakat akan kembali mendapatkan ketenangan batin sehingga mereka akan mampu menghadapi permasalahan hidup dengan lebih tenang. Karena ketenangan tersebut orang menjadi lebih berani untuk mengorbankan nilai kenikmatan ataupun vitalitas demi nilai kejiwaan, sehingga manusia tidak terlalu khawatir akan kehidupan yang dialami sejahtera ataupun tidak. Karena yang terpenting adalah dengan ketenangan batin yang mereka peroleh maka mereka dapat dengan jelas membedakan baik-buruk dan benar-salah segala sesuatu.

D. Nilai Kerohanian atau religius

Nilai kerohanian atau religius hanya akan tampak pada kita dalam objek yang dituju sebagai objek absolut. Hal ini dikarenakan keberadaan nilai religius tidak bergantung pada perbedaan waktu dan perbedaan orang yang membawanya (Alfan, 2013: 93).

Tradisi Ziarah Kubro memiliki tujuan yang sangat jelas yaitu menyadarkan manusia dalam kedudukannya sebagai makhluk Tuhan dan sebagai khalifah di bumi, baik bagi dirinya sendiri maupun bagi orang lain sehingga dapat mendekatkan diri kepada Sang Pencipta. 
Tradisi ini menjadi sarana untuk mengingat para ulama yang telah berjasa dalam penyebaran agama Islam di Kota Palembang.

Tujuan yang paling hakiki tersebut menunjukkan adanya nilai religius yaitu menuju realitas yang absolut dengan senantiasa melaksanakan dan meneguhkan keimanan terhadap Tuhan Yang Maha Esa. Nilai ini mengacu pada cinta terhadap realitas yang paling suci yaitu Tuhan. Dasar cinta itu dapat terlihat dengan jelas pada tradisi Ziarah Kubro. Tradisi ini merupakan realisasi dari cinta itu dalam bentuk tindakan nyata. Tradisi Ziarah Kubro menunjukkan bahwa manusia merupakan makhluk individu, makhluk sosial, dan makhluk religius yang dilingkupi oleh nilai-nilai kesenangan, kenikmatan, kejiwaan, dan religius.

Berdasarkan nilai-nilai yang telah ditemukan dalam tradisi Ziarah Kubro seperti tersebut di atas, maka hierarkhi nilai yang dapat ditemukan adalah sebagai berikut :

Nilai religius merupakan nilai yang paling tinggi kedudukannya dalam tradisi ini, karena seperti di jelaskan sebelumnya bahwa tradisi ini berorientasi pada Sang Pencipta melalui proses perenungan, tafakur, introspeksi, serta mendekatkan diri kepada Sang Khalik. Tujuan kepada realitas yang absolut tersebut menimbulkan konsekuensi bahwa seseorang harus dapat melepaskan motivasi lain yang mendorongnya melakukan tradisi ini.

Motivasi utama hanyalah demi mendapatkan keberkahan dari Sang Pencipta. Di bawah nilai religius terdapat nilai kejiwaan yaitu berupa diperolehnya ketenangan jiwa selama dan setelah menjalan tradisi Ziarah Kubro. Adapun nilai vital dan nilai kenikmatan dalam tradisi Ziarah Kubro akan menempati dua posisi terbawah, sebab dua nilai tersebut bukanlah orientasi utama.

\section{Refleksi Kritis}

Ziarah Kubro memiliki nilai-nilai yang secara hierarkis dalam pandangan Scheler bersifat objektif. Melalui hierarkhi nilai tersebut akan dapat diketahui nilai mana yang kedudukannya lebih tinggi dan nilai mana yang lebih rendah, sehingga akan memudahkan seseorang dalam memilih mana yang harus menjadi prioritas dalam hidupnya. Berdasarkan pemaparan pada sub bab sebelumnya dapat diketahui 
bahwa nilai yang utama dalam tradisi Ziarah Kubro adalah nilai religius yang dalam perspektif hierarkhi nilai Max Scheler nilai ini menempati posisi tertinggi karena lebih terarah pada entitas yang hakiki yaitu Sang Pencipta.

Pada praktiknya, kedudukan nilai yang lebih tinggi antara satu nilai dengan nilai yang lain menimbulkan perbedaan motivasi bagi masing-masing individu dalam melaksanakan Ziarah Kubro. Perbedaan motivasi tersebut tidak hanya sebagai pendorong individu untuk melaksanakan Ziarah Kubro, melainkan sebagai tolok ukur hasil yang akan diperoleh nantinya. Perbedaan motivasi seperti orientasi akan nilai kenikmatan dan nilai kehidupan saja akan mendorong manusia sekedar mengharapkan dampak atau konsekuensi secara fisik, yaitu yang dapat dirasakan langsung di dalam kehidupannya. Berbeda dengan individu yang beriorientasi pada nilai-nilai kejiwaan dan religius yang lebih mengesampingkan dampak fisik tersebut. Pada kenyataannya dalam Ziarah Kubro tidak semua orang mampu memfokuskan diri pada nilai religius. Hanya orang yang benar-benar mampulah yang dapat mencapai nilai religius dalam Ziarah Kubro. Hal ini disebabkan karena tidak semua orang mampu melepaskan nilai-nilai kenikmatan dan kehidupan sebagai motivasi dalam menjalankan tradisi tersebut. Meskipun demikian, perbedaan motivasi tersebut harus dapat disikapi secara bijaksana oleh masyarakat agar tradisi Ziarah Kubro sebagai sebuah kearifan lokal dapat tetap terjaga.

Berdasarkan pemaparan beberapa hal di atas, maka relevansi kajian tentang hierarki nilai Scheler adalah menunjukkan betapa beragamnya motivasi atau orientasi nilai individu dalam mengerjakan suatu tindakan. Pada konteks kekinian, perilaku atau tindakan seseorang cenderung dimotivasi oleh berbagai kepentingan jangka pendek termasuk dalam hal ini adalah orientasi nilai yang muncul dalam tradisi Ziarah Kubro. Sementara itu pemikiran Scheler yang lebih menekankan objektifitas nilai, dengan meletakkan nilai religius sebagai orientasi utama setiap tindakan akan dapat memberikan semacam rambu peringatan bagi manusia untuk mampu menyeimbangkan berbagai orientasi nilai yang masih jangka pendek tersebut dengan nilai religius sebagai nilai utama. Hal ini sekaligus 
memberikan pembelajaran bagi setiap individu agar mampu memilih hal yang bersifat lebih utama untuk diprioritaskan dan mau atau bersedia mengorbankan hal-hal lain yang tidak bersifat utama.

Pada konteks ini, nilai dalam perspektif Scheler harus dipahami dengan "hati" agar apa yang benar-benar menjadi tujuan hidup dapat diwujudkan serta lebih menghargai pilihan hidup orang lain. Jika hal ini dapat dilakukan maka sikap toleransi dan saling menghargai akan muncul sehingga akan berimplikasi pada semakin harmonisnya kehidupan berbangsa dan bernegara di Indonesia. Pada konteks yang lebih luas hal ini dapat digunakan bagi individu ataupun warga masyarakat untuk lebih memahami kembali nilai mana yang harus diutamakan serta meningkatkan kesadaran akan pentingnya religiusitas di dalam kehidupan bersama. Apabila individu di dalam kehidupan bermasyarakat lebih mengedepankan nilai-nilai religius maka hal ini akan berimplikasi pada semakin ditegakkannya nilai-nilai kebenaran serta kebaikan yang akan mengurangi serta mencegah perbuatan-perbuatan yang dapat merugikan tatanan kehidupan sosial.

\section{SIMPULAN}

Tradisi Ziarah Kubro pada masyarakat Kota Palembang merupakan sarana introspeksi diri, pemupuk kebersamaan, dan sekaligus bentuk penghormatan masyarakat terhadap para ulama yang menyebarkan agama Islam di Palembang. Dengan menggunakan perspektif hierarkhi nilai Max Scheler yang bersifat objektifis dapat diketahui bahwa di dalam tradisi Ziarah Kubro terdapat nilai kenikmatan, vital, kejiwaan, dan kerohanian/religius. Kesemua nilai tersebut muncul dalam motivasi dari dilakukannya tradisi Ziarah Kubro. Meskipun demikian sejatinya dalam tradisi Ziarah Kubro lebih ditekankan orientasi pada nilai yang bersifat kerohanian atau religius. Hal ini selaras dengan yang dipaparkan oleh Scheler bahwa nilai religius menempati posisi puncak dalam hierarkhi nilai, sehingga keberadaan nilai-nilai lain yang ada di bawahnya seharusnya turut mendukung dan mendorong ke arah terwujudnya nilai religius. 


\section{DAFTAR PUSTAKA}

Alfan, M., 2013, Pengantar Filsafat Nilai, Pustaka Setia, Bandung.

Basrowi, 2005, Pengantar Sosiologi, Bogor, Ghalia Indonesia.

Berg, L. W. C. V. d., 1989, Hadramaut dan Koloni Arab di Nusantara, INIS, Jakarta.

Collins, Elizabeth Fuller, 2004, "Islam and The Habits of Democracy: Islamic Organizations in Post-New Order South Sumatra" dalam Southeast Asia Program Publications at Cornell University No. 78.

Dekken, Alfons, 1974, Procees and Permanence in Ethics Max Scheler's Moral Philosophy, Paulist Press, New York.

Frondizi, Rasieri, 2009, Pengantar Filsafat Nilai, Pustaka Pelajar, Yogyakarta.

Gangas, Spiros, 2011, "Value, Knowledge and Solidarity: Neglected Convergences Between Emile Durkheim and Max Scheler" dalam Human Studies, No.4, Volume Vol. 18.

Jirzanah, 2008, "Aktualisasi Pemahaman Nilai Menurut Max Scheler Bagi Masa Depan Bangsa Indonesia" dalam Jurnal Filsafat, Vol. 18, No. 1 Tahun 2008, Fakultas Filsafat UGM, Yogyakarta.

Kabelen, M. C. S., 2014, "Fenomenologi Nilai Slametan Masyarakat Yogyakarta Dalam Perspektif Max Scheler", Tesis Fakultas Ilmu Budaya Program Studi Magister Filsafat Universitas Indonesia.

Kaelan, 2014, Pendidikan Pancasila, Paradigma, Yogyakarta.

Koentjaraningrat, 2015, Kebudayaan Mentalitas, dan Pembangunan, PT. Gramedia Pustaka Utama, Jakarta.

Kersten, Carool, 2017, A History of Islam in Indonesia, Edinburgh University Press, Edinburgh.

McCune, Timothy. J., 2014, "The Solidarity of Life: Max Scheler on Modernity and Harmony with Nature" dalam Ethics and Environment, Vol. 19, No. 1. 
Owens, Thomas. J., 1966, Scheler's "Emotive" Ethics dalam Spring, Vol. 16, No. 2.

Parmono, R., 1993, Konsep Nilai Menurut Max Scheler dalam Jurnal Filsafat Seri 16 November 1993, Fakultas Filsafat UGM, Yogyakarta.

Purwadi, 2010, Jejak para Wali dan Ziarah Spiritual, Kompas, Jakarta.

Qurtuby, S. A., 2017, Arabs and "Indo-Arabs" in Indonesia: Historical

Dynamics, Social Relations and Contemporary Changes dalam International Journal of Asia Pacific Studies, Vol. 13, No.2.

Scheler, Max, 1973, Formalism in Ethics and Non-Formal Ethics of Values, Northwestern University Press, Illinois.

Sulaiman, Munandar, 1995, Ilmu Budaya Dasar, PT. Eresco, Bandung.

Thamrin, Husni, 2013, "Kearifan Lokal dalam Pelestarian Lingkungan (The Local Wisdom in Enviromental Sustainable)" dalam Kutubkhanah, Vol. 16, No. 1.

Wahana, Paulus, 2016, "Menerapkan Etika Nilai Max Scheler Dalam Perkuliahan Pendidikan Pancasila Untuk Membangun Kesadaran Moral Mahasiswa" dalam Jurnal Filsafat, Vol. 26, No. 2, 2016, Fakultas Filsafat UGM, Yogyakarta. 